Provided for non-commercial research and education use. Not for reproduction, distribution or commercial use.

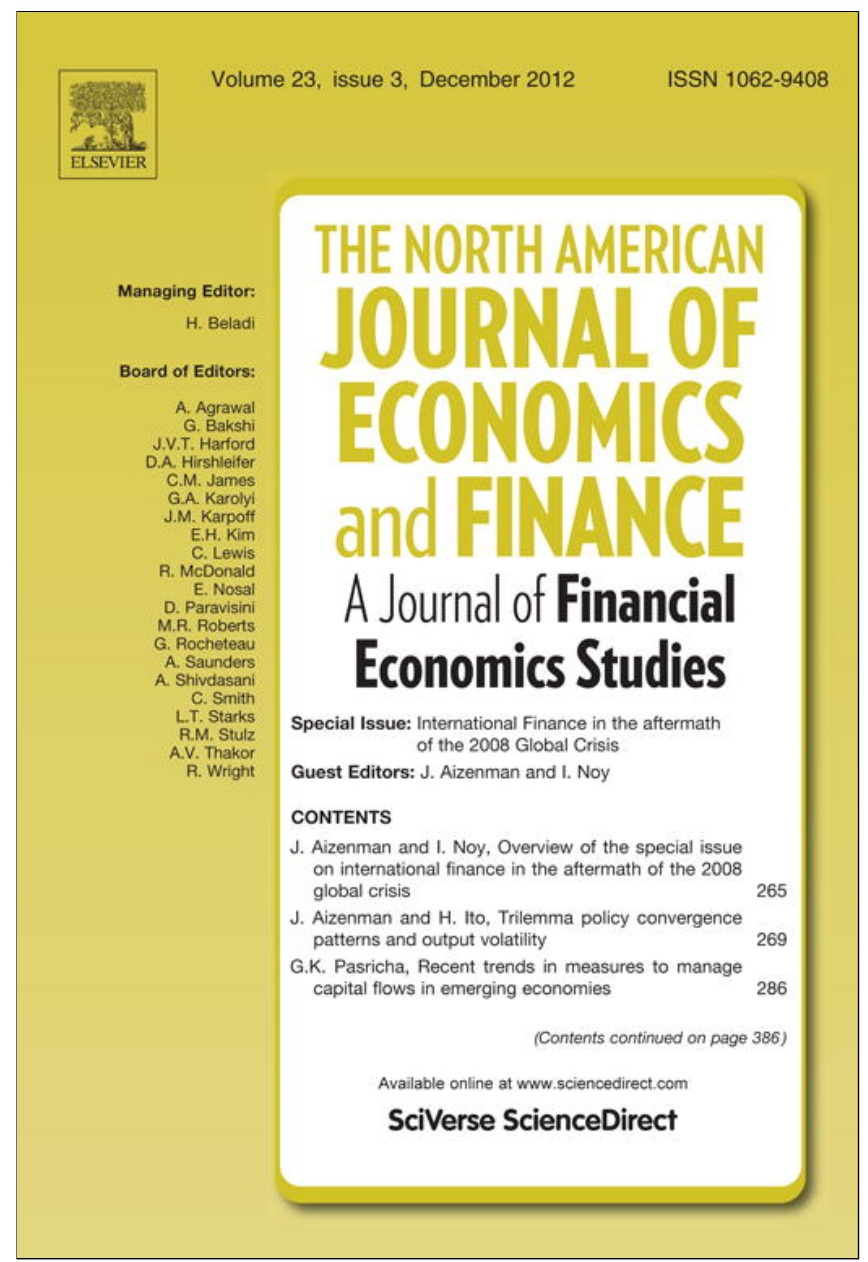

This article appeared in a journal published by Elsevier. The attached copy is furnished to the author for internal non-commercial research and education use, including for instruction at the authors institution and sharing with colleagues.

Other uses, including reproduction and distribution, or selling or licensing copies, or posting to personal, institutional or third party websites are prohibited.

In most cases authors are permitted to post their version of the article (e.g. in Word or Tex form) to their personal website or institutional repository. Authors requiring further information regarding Elsevier's archiving and manuscript policies are encouraged to visit:

http://www.elsevier.com/copyright 


\title{
Development threshold, capital flows, and financial turbulence
}

\author{
Ding Ding ${ }^{\mathrm{a}, *}$, Yothin Jinjarak ${ }^{\mathrm{b}}$ \\ a School of Business, SIM University, Singapore \\ b School of Oriental and African Studies, University of London, United Kingdom
}

\section{A R T I C L E I N F O}

\section{JEL classification:}

F21

F32

F43

G01

016

\section{Keywords:}

Capital flows

Capital flight

Economic development

Capital control

Financial liberalization

Financial crisis

\begin{abstract}
A B S T R A C T
We study capital flows in a panel of 130 countries, and derive the implications for the observed patterns of capital flows and capital controls before and into the crisis of 2008-11. We find that the size of capital flows is positively correlated with country's income level. In addition, capital flight has a non-linear relationship with the income level. Using the Hansen threshold estimation, we identify a three-stage threshold effect: for low-income countries (GDP per capita below US\$3,000), capital flight increases as the income level rises; and only after the economy passes a threshold level (GDP per capita above US\$ 5,000), capital flight declines with income. We conclude with a case study of Brazil and Korea, observing that the decisions to implement capital control measures tend to be pushed around by the feedbacks among economic growth, currency appreciation, and the global financial conditions.
\end{abstract}

(c) 2012 Elsevier Inc. All rights reserved.

\section{Introduction}

This paper provides a detailed investigation on the capital flows in a panel of 130 countries (covering advanced, emerging and less developed countries) over the past three decades. The objective is to compare the patterns and determinants of capital flows, and understand how economic fundamental affect capital flows, as well as the policies directed at capital flows of recent years, i.e. capital controls, especially before and into the crisis of 2008-11. We consider four measures of capital flows: (i) Total capital inflow, (ii) Total capital outflow, (iii) Net capital outflow, and (iv) Capital flight. Firstly, we

\footnotetext{
* Corresponding author.

E-mail addresses: dingding@unisim.edu.sg (D. Ding), yj5@soas.ac.uk (Y. Jinjarak).
} 
update the estimates on the capital flows for the 130 countries spanning 24 years from 1980 to 2003. The estimation results show that there are differences in the patterns of these measures of capital flows across developing and industrial countries. Rich countries experience higher volumes of total capital inflows and outflows, and also have higher net capital outflows. Poor countries, which are less open in trade and financial sectors, receive less total capital inflow and experience higher outward capital flight during certain stages of development, especially when their capita income level is relatively low.

Secondly, from both cross-sectional and panel regression estimation results, we find that there is a non-linear relationship between capital flight and economic development. There is an inverse U-shape relationship between capital flight and income level, as measured by GDP per capita. Using the Hansen threshold estimation method, we identify a three-stage threshold effect of economic development on capital flight: below the threshold, capital flight increases as income level rises; Only after passing the threshold level of income, capital flight decreases with GDP per capita. This threshold effect is unique to capital flight and economic development; a similar threshold effect for net outflows, total outflow, and total inflow could not be detected.

Lastly, we look at the cases of Brazil and Korea, both of which are beyond our estimates of the threshold development level. While the concern over currency appreciation and volatility of capital flows continues to be important, the observations on their recent management of capital flows suggest that a country's decision to implement the control measures has become more influenced by the global market conditions especially since the crisis of 2008.

This paper is related to several strands of the capital flow literature. The first explores the driving forces of international capital movements, many of which attempt to establish theoretical models to explain how different factors (i.e. wealth, investment return, risks) affect capital flows. ${ }^{1}$ The second studies capital flight, including both theoretical and empirical studies on the definition, measurement and determinants of capital flight. ${ }^{2}$ As a special category of capital outflows, capital flight has attracted interests since the 1980s debt crisis in developing countries; due to its distinct nature, the measurements and determinants of capita flight are different from typical capital flows. The third set of literature examines linkages between financial liberalization and international capital movements; a majority of these papers attempt to measure financial openness and explore the effects of financial openness on capita flows, economic growth, and financial crisis. ${ }^{3}$

The rest of the paper is structured as follows. Section 2 overviews the data and methodology for measuring capital flows and capital flight, and reports the patterns of capital flows in a sample of 130 countries, using time-series and 5-year average of individual and groups of countries. Section 3 provides statistical analysis on capital flows. An interesting observation from both cross-sectional and panel data regressions is that capital flight, unlike other types of capital flows, shows a distinct nonlinear relationship with income level (GDP per capita in PPP). To check the robustness of this finding, we also test the non-linear relationship using the Hansen Threshold model. In Section 4, we provide a case study of capital controls of Brazil and Korea. Section 5 concludes.

\footnotetext{
1 The standard neoclassical models state that capital flows are driven by scarcity, and therefore capital should flow from rich to poor countries. Lucas (1990) points out a paradox to the standard theory: capital flows from rich to poor countries seem small relative to the level predicted by the models. Despite the rapid growth of international capital markets and financial integration, the capital inflows to developing countries remain low compared to the levels observed among the OECD countries. Theoretical and empirical studies offer several explanations to the paradox (see for example Alfaro, Kalemli-Ozcan, \& Volosovych, 2008; Gourinchas \& Jeanne, 2007; Ju \& Wei, 2006), but the dust has yet to settle. See Jones, Ceolho, et al. (1986), Lane and MilesiFerretti (2002a, 2002b), Reinhart and Rogoff (2004), Alfaro and Hammel (2007), Gourinchas and Jeanne (2007), Verdier (2008), Devereux and Sutherland (2009), and Wincoop and Tille (2010).

2 The early use of this phrase is Kindleberger (1938) who defines capital flight as "abnormal flows propelled from a country. . .by. . .one or more complex list of fears and suspicions". According to Kindleberger, a capital outflow should be exceptional, sudden, and arise from adverse, almost pathological expectations for it to qualify as capital flight. The working definition of 'capital flight' was revised by Dooley (1986), Cuddington (1986), Lessard and Williamson (1987), and Cumby and Levich (1987). See also Collier, Hoeffler, and Pattillo (1999) and Ndikumana and Boyce (2001, 2003).

3 See Edwards (2005, 2007) and Edwards and Rigobon (2009), Evans and Hnatkovska (2005), Chinn and Ito (2006, 2008), Prasad, Rajan, et al. (2007), Honig (2008), and Neumann, Penl, and Tanku (2009).
} 

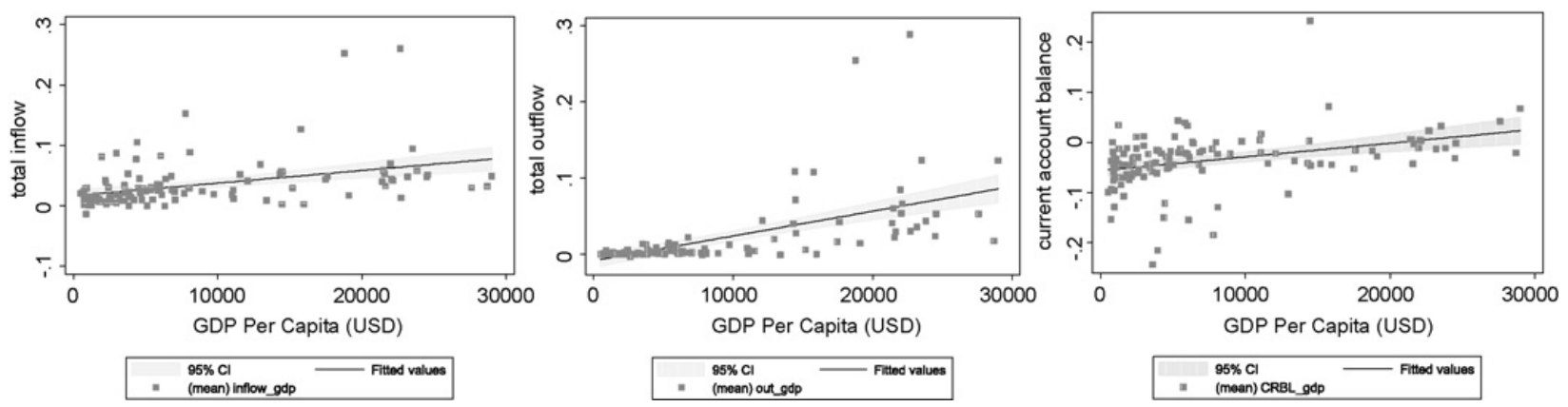

Fig. 1. Capital flows and income level. (a) Total capital inflow. (b) Total capital outflow. (c) Net capital outflow. Notes: The figure provides a scatter plot of the relationship between capital flows and the level of income for each country. In (a) the $Y$-axis is the estimated total capital inflow to GDP ratios; (b) the $Y$-axis is total capital outflow to GDP ratios; (c) net capital outflow and graph. In each graph, the X-axis is GDP per capita, PPP in US dollar. Average data over the period of 1980-2003 are used for 130 countries.

\section{Patterns of capital flows}

We examine in details the aggregate capital flows, including: total capital inflow, total capital outflow, net capital outflow and capital flight. Total capital inflow, which is the sum of short- and longterm capital inflows as reported under FDI inflow and portfolio inflow in the balance of payment. Total capital outflow is defined as the sum of short-and long-term capital outflows as reported in the balance of payments; it consists of foreign direct investment (FDI) abroad and portfolio investment outflow. Data on FDI and portfolio investment flows are obtained from the International Financial Statistics (Lines 78bdd and 78bfd for outflow and Lines 78bed and 78bgd for inflow). The dataset covers 130 countries over the period of 1980-2003. Net capital outflow is taken as a current account surplus, obtained from the World Development Indicators. Current account balance is the sum of net exports of goods, services, net income, and net current transfers. A positive figure, or a surplus, implies net capital outflow from and country, and a negative figure implies net capital inflow.

To measure Capital flight, we use the broadest measure-the residual (or World Bank) method. ${ }^{4}$ The World Bank method compares the sources of capital (the change in external debt and net foreign direct investment), with the uses of capital (a current account deficit and the change in official reserves). Capital flight occurs when sources of capital exceed uses of finance, hence, the residual: $C F=\triangle D e b t+F I-C A D-\triangle F R$, where $C F$ is capital flight according to the residual method, $\Delta$ denotes change, Debt is stock of gross external debt reported in the World Bank data, FI is the net foreign investment inflows, $C A D$ is the current account deficit and $F R$ is the stock of official foreign reserves. This measure covers all unreported capital outflow, including assets of both the banking and nonbanking sectors. The data used for the calculation of capital flight are taken from various sources. Data on capital flight from developing countries are taken from the World Development Indicators 2005 (WDI), while data from the Source OECD are used for computing capital flight from all the industrial counties and a number of developing countries. ${ }^{5}$ We use extensive sources of databases to derive the controlling variables, detailed in Appendix A. While we try to be comprehensive on the data collection across years and countries, the number of observation for each country ranges from 15 to 24 years.

\subsection{Capital flows E income}

Figs. 1 and 2 plot the four types of capital flows as percentage of GDP, by GDP per capita (PPP). As shown in Fig. 1, the three types of flows, i.e., total capital inflow, total outflow and net capital outflow

\footnotetext{
${ }^{4}$ There are at least three reasons for using the residue method: (i) it is the most often used method in capital flight literature since the 1990s; (ii) it is the broadest measure, covering all unreported capital outflow so as to minimize potential biases in narrower terms; (iii) the data availability for this method allows the largest sample size for this study. See also the Dooley method, the hot money method, and the asset method in the references cited.

${ }^{5}$ Only data on External Debt for industrial countries and a few developing countries are from Source OECD, whereas the rest of data used for capital flight calculation are all from WDI.
} 

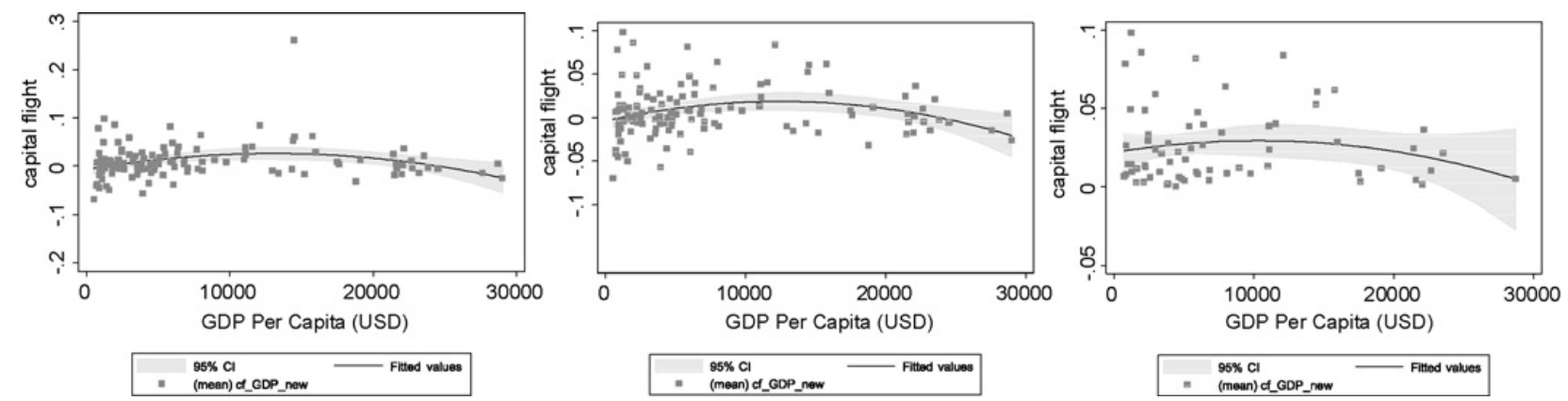

Fig. 2. Capital flight and income level. (a) 130 countries. (b) Without outlier. (c) Capital flight. Notes: The figure provides a scatter plot of the relationship between capital flight and the level of economic development for each country: (a) plots average capital flight for 130 countries; (b) is for 129 countries after drop the outlier, Kuwait; (c) shows only countries with positive capital flight. In each graph, the $X$-axis is GDP per capita, PPP in US dollar and the $Y$-axis is estimated total capital inflow to GDP ratios. Average data over the period of 1980-2003 are used for 130 countries.

are all positively correlated with a country's income level. As shown in Fig. 2, there seems to be a non-linear relationship between capital flight and economic development. We can see more clearly from Fig. 2 panel (b) (after dropping the outlier Kuwait) the inverse U-shape between capital flight and GDP per capital for 129 countries in the sample. This inverse U-shape may imply that there is a threshold effect of economic development on capital flight: below the threshold level of economic development, capital flight will increase as economy grows; until when the economy grows into a stage beyond the threshold level, capital flight will begin to decline.

Table 1 provides a detailed comparison between capital flight and capital flows from developing and industrial countries. Average annual capital flight in US\$ does not differ much between industrial and developing economies; however, when taken as a ratio to GDP, capital flight from developing countries is almost twenty times of that from industrial countries. On the other hand, normal capital outflow shows an opposite pattern from capital flight: In US\$, capital outflow from industrial countries is more than 100 times of that from developing countries. When we consider the effect of economy size, capital outflow as ratio to GDP from industrial counties is still more than 5 times of that from developing countries. In summary, capital flight and normal capital outflow show opposite patterns for industrial and developing countries: developing countries register high levels of capital flight but have low capital outflow, while industrial counties experience large volume of capital outflow and almost no capital flight or even negative capital flight.

\subsection{Capital flows \& financial openness}

Two commonly used methods for measuring financial integration are considered. The first is the capital account openness index (KAOPEN) developed by Chinn and Ito (2006), constructed as the first principle component of the four IMF binary variables in the Annual Report on Exchange Arrangements and Exchange Restrictions. It has a wide coverage (more than 100 countries) for a long time period

\section{Table 1}

Capital flows and capital flight.

\begin{tabular}{|c|c|c|c|c|}
\hline \multirow[t]{2}{*}{ Flows/country group } & \multicolumn{2}{|c|}{ Industrial countries (Obs: 22) } & \multicolumn{2}{|c|}{ Developing countries (Obs: 108) } \\
\hline & Mean & Std. Dev. & Mean & Std. Dev. \\
\hline Capital flight (US\$ mil.) & 701 & 10400 & 642 & 2250 \\
\hline $\mathrm{CF} / \mathrm{GDP}(\%)$ & $0.089 \%$ & $1.643 \%$ & $1.663 \%$ & $4.378 \%$ \\
\hline Net capital outflow (US\$ mil.) & -3520 & 39000 & -289 & 2050 \\
\hline NetOutflow/GDP (\%) & $-0.434 \%$ & $2.989 \%$ & $-4.320 \%$ & $6.039 \%$ \\
\hline Total capital inflow (US\$ mil.) & 36200 & 53000 & 1170 & 3250 \\
\hline Inflow/GDP (\%) & $6.597 \%$ & $6.378 \%$ & $2.494 \%$ & $2.931 \%$ \\
\hline Total capital outflow (US\$ mil.) & 35400 & 37600 & 332 & 1030 \\
\hline Outflow/GDP (\%) & $4.539 \%$ & $7.261 \%$ & $0.860 \%$ & $1.765 \%$ \\
\hline
\end{tabular}



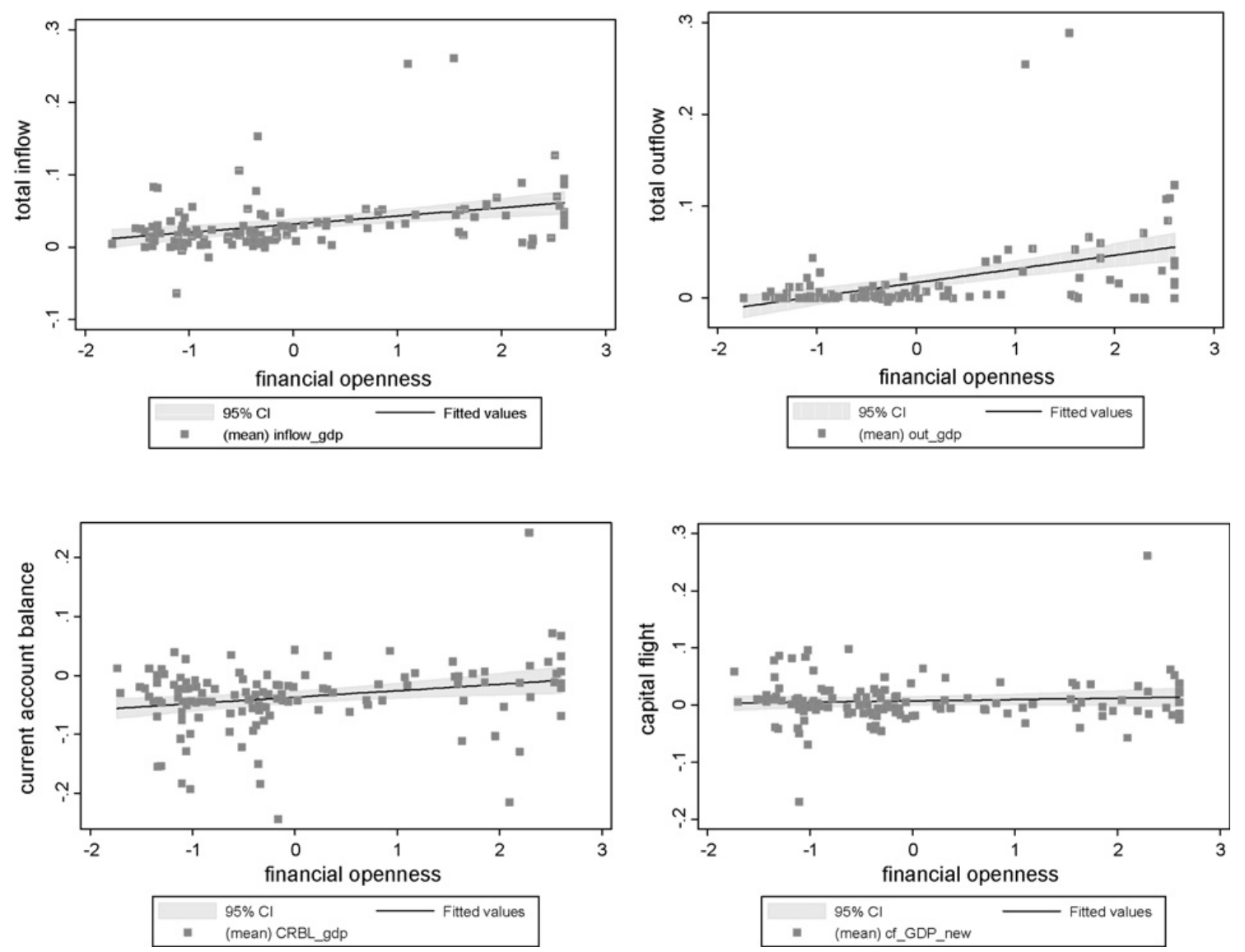

Fig. 3. Capital flows and financial openness. (a) Total capital inflow. (b) Total capital outflow. (c) Current account surplus. (d) Capital flight. Notes: The figure provides a scatter plot of the relationship between four types of capital flows (capital flight, net capital outflow, total capital inflow and outflow) and the level of financial openness for each country. In graph (a) the $Y$-axis is estimated total capital inflow to GDP ratios, in graph (b) the Y-axis is total capital outflow to GDP ratios, graph (c) net capital outflow and graph (d) capital flight to GDP ratios. In each graph, the $X$-axis is the Chinn-Ito measure of capital account openness. Average data are used for 130 countries over the period of 1980-2003.

(1970-2003). The second measure of financial openness is the Capital Mobility index (Cap_Inx) constructed by Edwards (2007), which combines Quinn (2003) and Mody and Murshid (2002), and with information from country-specific sources. The two measures are highly correlated, with a correlation of 0.88 . Fig. 3 shows the scattered plots of the four types of capital flows to GDP ratio by financial openness for the 130 countries. The $X$-axis is the KAOPEN (Chinn \& Ito, 2006) measure of capital account openness. Except capital flight, the size of capital flows is positively correlated with financial openness. The similar patterns can be found using the other financial openness measure.

\subsection{Capital flows E economic growth}

Fig. 4 provides the scatter plots of capital flows by the level of GDP per capita growth. The top row suggests that higher levels of total capital inflows and outflows are correlated with higher economic growth rate. The bottom-left plot shows a negative association: net inflows tend to enter fast growing counties. The bottom-right plot suggests a negative association between capital flight and growth.

\section{Empirical estimation}

In this section, we examine the pattern of capital flows formally, controlling for fundamentals and economic openness. The sample includes annual observations for a total of 130 countries, of which 22 are industrial countries and 108 are developing countries, covering the period 1980-2003. The baseline regression models include cross-country OLS estimations using sample averaged data, panel 

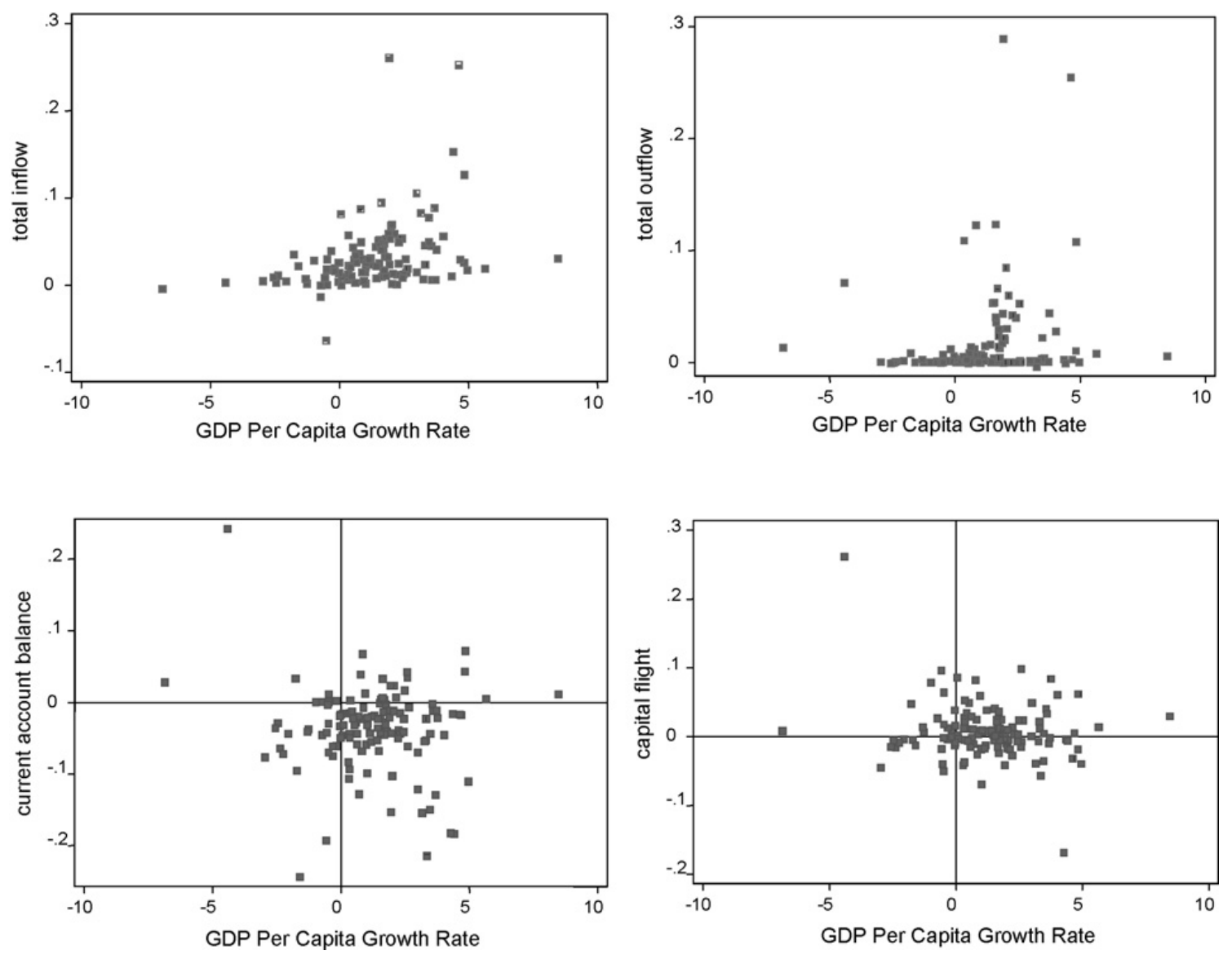

Fig. 4. Capital flows and economic growth. (a) Total capital inflow. (b) Total capital outflow. (c) Net capital outflow. (d) Capital flight. Notes: The figure provides a scatter plot of the relationship between the four types of capital flows (capital flight, net capital outflow, total capital inflow and outflow) and the rate of economic growth (GDP per capita). In graph (a) the $Y$-axis is the estimated total capital inflow to GDP ratios; in graph (b) the $Y$-axis is total capital outflow to GDP ratios; graph (c) net capital outflow; and graph (d) capital flight to GDP ratios. In each graph, the X-axis is the GDP per capita growth rate. The plots use average data for 119 countries over the period of 1980-2003.

estimation using annual data and five-year average data. We add to the literature by checking the non-linear relationships between capital flows and the controls, using the Hansen threshold regression methods.The dependent variables are capital flows to GDP. We use a number of economic controls, including GDP per capita, financial openness, trade openness, education, inflation, growth, real interest rate, currency overvaluation, corruption, political risk, institutional quality. Table 2 reports the correlation matrix of the variables. As shown, capital inflow and outflow are highly correlated, with a correlation coefficient of 0.75 . Net capital outflow and capital flight are also highly correlated, with a correlation of 0.55 . Net capital outflow, total capital inflow and total outflow are all positively correlated with fundamental factors, including income, trade and financial openness, education, political development and other institutional variables. The determinants for capital flight, however, could not be clearly detected in the correlation matrix. Among the controlling variables, multi-collinearity could be an issue as, for instance, GDP per capita is highly correlated with a number of other explanatory variables. In order to avoid this problem, some variables that have a sample correlation with GDP per capita higher than 0.7 are dropped from the baseline estimation.

\subsection{Baseline estimation}

Both cross-country OLS regressions and panel regressions have been performed to test the significance of explanatory variables. One potential problem with developing country data is the possibility of significant measurement error in annual data and business cycle fluctuations. We also construct a panel of non-overlapping 5-year average for each country. Applying this 5-year average panel on all 
Table 2

Correlation matrix of capital flows and explanatory variables.

\begin{tabular}{|c|c|c|c|c|}
\hline & CFlight/GDP & NetOut/GDP & Inflow/GDP & Outflow/GDP \\
\hline NetOut/GDP & $0.5480^{*}$ & 1 & -0.0828 & $0.3483^{*}$ \\
\hline Inflow/GDP & -0.0037 & -0.0828 & 1 & $0.7537^{*}$ \\
\hline Outflow/GDP & 0.0737 & $0.3483^{*}$ & $0.7537^{*}$ & 1 \\
\hline GDPPC & 0.0517 & $0.3816^{*}$ & $0.4074^{*}$ & $0.5984^{*}$ \\
\hline CAP INX. & 0.0350 & $0.2079^{*}$ & $0.4330^{*}$ & $0.5150^{*}$ \\
\hline KAOPEN & 0.0758 & $0.2431^{*}$ & $0.3588^{*}$ & $0.4627^{*}$ \\
\hline SCHOOL & 0.1079 & $0.3337^{*}$ & $0.4028^{*}$ & $0.4002^{*}$ \\
\hline INF & 0.0671 & $-0.2661^{*}$ & 0.0089 & -0.1069 \\
\hline GROWTH & $-0.1684^{*}$ & -0.0972 & $0.3589^{*}$ & 0.1454 \\
\hline RIR & -0.1237 & -0.1226 & -0.0045 & -0.0147 \\
\hline POLITY & -0.0705 & 0.1275 & $0.3714^{*}$ & $0.3119^{*}$ \\
\hline OVAL & -0.0440 & $-0.3536^{*}$ & $-0.2261^{*}$ & -0.1751 \\
\hline CORR. & -0.0945 & $0.1740^{*}$ & $0.4556^{*}$ & $0.5026^{*}$ \\
\hline POL.RISK & 0.0079 & $0.3496^{*}$ & $0.5385^{*}$ & $0.5719^{*}$ \\
\hline INST. & -0.0192 & $0.3141^{*}$ & $0.5301^{*}$ & $0.5545^{*}$ \\
\hline OPENF & $0.2579^{*}$ & $0.2009^{*}$ & $0.4348^{*}$ & $0.4559^{*}$ \\
\hline
\end{tabular}

Notes: This table presents the pair-wise correlations between the four dependant variables: CFlight/GDP, NetOut/GDP, Inflow/GDP and Outflow/GDP and the economic controls. Average data for the period 1980-2003 are used for each country.

* $10 \%$ significance level.

the variables for the period 1980 to 2003 reduces the 24 annual observations to 5 time-series observations. The novel part of our estimation is to investigate the effect of development threshold on the pattern of capital flows. This can be done by (i) including the squared term of the controlling variable; (ii) conducting a formal threshold estimation. Following (i), GDP per capita and its squared term allow for a possible non-linear relationship with capital flows:

$$
C F_{i}=\alpha_{i}+\beta_{1} Y_{i}+\beta_{2} Y_{i}^{2}+\beta_{3} Z_{i}^{\prime}+\varepsilon_{i},
$$

where $C F_{i}$ is average capital flows as ratios to GDP, $\alpha_{i}$ is a constant (subscript $i$ indicates countries), $Y_{i}$ is the average GDP per capita PPP, a proxy of economic development, and $Y_{i}^{2}$ is its quadratic form. $Z_{i}^{\prime}$ is a vector of all other explanatory variables, and $\varepsilon_{i}$ is a random error term.

\subsubsection{Cross-country regression}

Table 3 provides the cross-country regression results. A result that appears to be fairly robust across countries is the effects of GDP per capita and its squared terms are significant in the regressions of capital flight. For the other three types of capital flows, only the coefficients of the GDP per capita terms are significant, but not the squared terms (i.e. the net outflow equation; the squared term are dropped in the other two to increase the degree of freedom), indicating that these types of flows may be linearly correlated with income. Moreover, for regressions on capita flight, the coefficient on the GDP per capita term is significantly positive and the coefficient on the quadratic term is significantly negative. This suggests that the relationship between capital flight and economic development is not linear, but rather an inverse U-shape.

An explanation for this inverse U-shaped correlation of capital flight and GDP per capita may be that during the initial stage of economic development, i.e. low level of GDP per capita, the domestic residents are gradually accumulating wealth domestically and abroad, the latter which is the source for both capital outflows and outgoing flight of capital. Capital flight, in particular, is encouraged by unstable property rights, domestic economic and political condition; the domestic residents choose to take their wealth aboard in other safer places. At this stage, inward foreign investment and foreign lending may lead to even higher capital flight. As the economy continues to grow, economic and political conditions improve and better institutions are established, the residents gain more confidence in the domestic economy, and no longer need to put their assets abroad to avoid government control or potential losses from expropriation. Consequently, capital flight may decrease as GDP per capita and economic development has improved. 
Table 3

Cross-country regression results.

\begin{tabular}{lllll}
\hline & CFlight/GDP & NetOut/GDP & Inflow/GDP & Outflow/GDP \\
\hline GDPPC & 0.889 & 0.599 & 0.107 & 0.271 \\
GDPPC2 & $(0.214)^{* * *}$ & $(0.255)^{* *}$ & $(0.092)$ & $(0.097)^{* * *}$ \\
RIR & -0.031 & -0.012 & - & - \\
& $(0.007)^{* * *}$ & $(0.009)$ & - & -0.033 \\
INF & -0.009 & 0.014 & -0.041 & $(0.056)$ \\
& $(0.047)$ & $(0.056)$ & $(0.053)$ & 0.002 \\
POLITY & -0.001 & -0.003 & 0.005 & $(0.004)$ \\
& $(0.004)$ & $(0.004)$ & $(0.004)$ & -0.002 \\
OPENF & -0.359 & -0.385 & 0.119 & $(0.104)$ \\
& $(0.088)^{* * *}$ & $(0.104)^{* * *}$ & $(0.099)$ & 0.62 \\
GROWTH & 0.182 & 0.223 & 0.532 & $(0.127)^{* * *}$ \\
KAOPEN & $(0.111)$ & $(0.132)^{*}$ & $(0.121)^{* * *}$ & 0.162 \\
& -0.496 & -0.33 & 0.483 & $(0.235)$ \\
OVAL & $(0.194)^{* * *}$ & $(0.231)$ & $(0.222)^{* * *}$ & 0.707 \\
& 0.555 & 0.659 & 0.614 & $(0.506)$ \\
Constant & $(0.432)$ & $(0.513)$ & $(0.479)$ & 0.001 \\
& 0 & -0.013 & -0.001 & $(0.004)$ \\
Observations & $(0.004)$ & $(0.004)^{* * *}$ & $(0.004)$ & -3.122 \\
$R$-squared & -1.016 & -4.429 & -1.189 & $(1.026)^{* * *}$ \\
\hline
\end{tabular}

Notes: Standard errors in parentheses. This table reports cross-country regressions using the country-average data for all the variables over the period 1980-2003. Dependent variables are the capital flight, net capital outflow, total capital inflow and total capital outflow to GDP ratios. Explanatory variables include: GDPPC is GDP per capita, PPP. GDPPC2 is the square term of GDPPC. OPENF is the gravity model fitted trade openness. POLITY is the political rating of democracy (10) and autocracy ( -10$)$. $R I R$ is the annual domestic real interest rate. INF: Annual domestic inflation rate, consumer prices (annual \%). KAOPEN is the Chinn-Ito measure for capital account openness. OVAL is exchange rate over-valuation. GROWTH is the annual GDP per capita growth rate.

\footnotetext{
* Significant at $10 \%$.

*** Significant at $5 \%$.

**** Significant at $1 \%$.
}

The coefficient on trade openness is positive and significant for all other types of capital flows, but not for capital flight. This suggests that openness may stimulate the size of normal capital flows across borders, but not capital flight. We also test the possibility of a non-linear relationship between trade openness and capital flight; however, the coefficient on the squared term of trade openness is not significantly different from zero. On one hand, trade openness may lead to higher capital flight because it provides easier access to foreign markets, thereby increasing capital flight through the misinvoicing. On the other hand, higher trade openness also indicates a higher level of development in the domestic financial markets, better institutions and investment environment; higher openness may reduce capital flight as holding domestic assets become more attractive. The coefficients of political development are negative for regressions on capital flight and net capital outflows. This suggests that capital flight decreases as a country become more politically open to public and more democratic; dictatorship and autocracy encourage residents to place their wealth abroad to avoid the control from their government. The sign and significance of the POLITY variable confirm with the theoretical hypothesis. Among all the other additional variables, the cross-country regressions show that the economic growth rate is another important factor. In the regression on capital flight, the coefficient of growth rate is significantly negative, indicating that higher economic growth rate reduces capital flight. In the regression on total capital inflow, the coefficient of growth rate is significantly positive, indicating higher growth rate attracts more capital inflows.

\subsubsection{Panel estimation}

To increase the sample size and the efficiency of estimation, we pool all the annual data and apply the panel estimation. The panels are non-overlapping 5 year averages for each country; using 
Table 4

Panel estimation.

\begin{tabular}{lllll}
\hline & CFlight/GDP & NetOut/GDP & Inflow/GDP & Outflow/GDP \\
\hline GDPPC & 2.906 & 1.251 & 0.722 & 1.298 \\
GDPPC2 & $(0.828)^{* * *}$ & $(0.450)^{* * *}$ & $(0.180)^{* * *}$ & $(0.193)^{* * *}$ \\
RIR & -0.052 & - & - & - \\
INF & $(0.021)^{* *}$ & - & - & -0.018 \\
& -0.064 & -0.011 & 0.005 & $(0.02)$ \\
POLITY & $(0.036)^{*}$ & $(0.02)$ & $(0.02)$ & 0.001 \\
& 0.001 & -0.001 & 0.000 & $(0.00)$ \\
OPENF & $(0.00)$ & $(0.00)$ & $(0.00)$ & -0.055 \\
& -0.195 & 0.046 & -0.010 & $(0.11)$ \\
GROWTH & $(0.17)$ & $(0.09)$ & $(0.10)$ & -1.418 \\
KAOPEN & -0.713 & -1.216 & -1.275 & $(0.404)^{* * *}$ \\
OVAL & $(0.70)$ & $(0.383)^{* * *}$ & $(0.379)^{* * *}$ & 0.403 \\
& 0.385 & 0.092 & 0.300 & $(0.135)^{* * *}$ \\
Constant & $(0.228)^{*}$ & $(0.12)$ & $(0.128)^{* * *}$ & 0.304 \\
& 0.912 & 0.244 & 0.450 & $(0.42)$ \\
Country dummy & $(0.69)$ & $(0.38)$ & $(0.390)$ & 0.002 \\
Year dummy & 0.013 & 0.002 & 0.000 & $(0.00)$ \\
Observations & $(0.004)^{* * *}$ & $(0.00)$ & $(0.00)$ & 3.565 \\
$R$-squared & -19.942 & 10.197 & 24.638 & $(3.61)$ \\
\hline
\end{tabular}

Notes: Standard errors in parentheses. This table reports panel estimation results using the five-year average data over the period 1980-2003; each country has 5 observations. We include dummy variables for each time period to control the time effects. Dependent variables are the capital flight, net capital outflow, total capital inflow and total capital outflow to GDP ratios. Explanatory variables included: GDPPC is GDP per capita, PPP. GDPPC2 is the square term of GDPPC. OPENF is the gravity model fitted trade openness. POLITY is the political rating of democracy (10) and autocracy $(-10)$. RIR is the annual domestic real interest rate. INF: Annual domestic inflation rate, consumer prices (annual \%). KAOPEN is the Chinn measure for capital account openness. OVAL is exchange rate over-valuation. GROWTH is the annual GDP per capita growth rate.

* Significant at $10 \%$.

** Significant at $5 \%$.

*** Significant at $1 \%$.

1980-2003 period, this results in 5 observations for each country. We also include time dummy and country dummy variables in the regressions to control for time effect and country specific effect. The equation we use for the panel regressions is

$$
C F_{i t}=\alpha_{i}+\beta_{1} Y_{i t}+\beta_{2} Y_{i t}^{2}+\beta_{3} Z_{i t}^{\prime}+\lambda_{t}+\varepsilon_{i t},
$$

where the subscript $i$ represents country, and subscript $t$ represents time. $C F_{i t}$ is average capital flows as a ratio to GDP; $\alpha_{i}$ is a constant country fixed effect; $Y_{i t}$ is the average GDP per capita (PPP); and $Y_{i t}^{2}$ is its quadratic form. $Z_{i t}^{\prime}$ is a vector of all other explanatory variables, $\lambda_{t}$ is the time effect, and $\varepsilon_{i t}$ is an error term.

Table 4 shows results from panel regression with both time and country dummies. The panel regression results support the results from cross-country analysis. The coefficients of GDP per capita and its quadratic term are consistently significant in the both cross-country and panel regressions. Net capital outflows, total capital inflows and outflows are all linearly and positively correlated with GDP per capita. When both time and country dummy variables are included in the regressions, the effects of the POLITY variable has become weaker, while the effects of trade openness turn negative. Comparing the cross-country estimation and the panel results suggests that the relationship between capital flows and GDP per capita are the most robust. 


\subsection{Threshold regression}

From both the cross-country and the panel regressions, the robust non-linearity between capital flight and a country's GDP per capita suggests an inverse U-shape relationship. We examine further by applying the threshold regression (Hansen, 1999, 2000). Several points on the threshold estimation are in order. First, it does not require any specified functional form of nonlinearity, and the number and location of thresholds are endogenously determined by the data. Second, it provides an asymptotic distribution theory to construct confidence intervals for the parameters. A bootstrap method is applied to assess the statistical significance of the threshold effects.

We follow Hansen (1999) by using bootstrap procedure to test the null hypothesis of a linear formulation against a threshold alternative. The threshold model assumes the data is generated by $\left\{y_{i}, x_{i}, q_{i}\right\}_{i=1}^{n}$, where $y_{i}$ and $q_{i}$ are observations on the dependent variable and a threshold variable, respectively, and $x_{i}$ is a $p \times 1$ vector of explanatory variables. The threshold variable $q_{i}$ splits the sample into different groups. The threshold model is given by

$$
\begin{array}{ll}
y_{i}=x_{i}^{T} \beta_{1}+\varepsilon_{i}, & q_{i} \leq \gamma \\
y_{i}=x_{i}^{T} \beta_{2}+\varepsilon_{i}, & q_{i}>\gamma
\end{array}
$$

The model can be written in a single equation form by defining a dummy variable $d_{i}(\gamma)=I\left(q_{i} \leq \gamma\right)$ where $I(\cdot)$ denotes the indicator function. If we denote $x_{i}(\gamma)=x_{i} d_{i}(\gamma)$, the above could be expressed as

$$
y_{i}=x_{i}^{T} \beta+x_{i}^{T}(\gamma) \theta_{n}+\varepsilon_{i},
$$

where $\beta=\beta_{2}$ and $\theta_{n}=\beta_{1}-\beta_{2}$, which is the threshold effect, allowing all the regression coefficients to differ between sample groups. The proposed solution is to let $\theta_{n} \rightarrow 0$ as $n \rightarrow \infty$. This can be achieved by holding $\beta_{2}$ fixed thereby making $\beta_{1}$ approach $\beta_{2}$ as $n \rightarrow \infty$. Hansen (1999) also provides an algorithm that searches over the values of $\gamma$ using conditional OLS regressions based on a sequential search over all $\gamma=q_{i}$, for $i=1,2, \ldots, n$. The procedure also provides the estimates of $\beta$ and $\theta$.

The hypothesis for the threshold test is whether the threshold model is statistically significant relative to a simple linear specification. The null hypothesis describes the simple linear specification and can be expressed as:

$$
H_{0}: \beta_{1}=\beta_{2}
$$

As the threshold parameter $\gamma$ is not identified under $H_{0}$, we follow Hansen (1999) and use a heteroskedasticity-consistent Lagrange Multiplier (LM) bootstrap procedure to test the null hypothesis of a linear formulation against a threshold alternative. The $p$ values are then computed by a fixed bootstrap method. The $x_{i}$ values are used as regressors and the bootstrap-dependent variable is generated from $N\left(0, \hat{e}_{1}^{2}\right)$, where $\hat{e}$ is the OLS residual from the estimated threshold model. Hansen (1999) shows that this procedure yields asymptotically correct $p$ values. Note that if the above null hypothesis is rejected and a threshold level is identified, we should test again the threshold model against a linear specification after dividing the original sample according to the threshold thus identified. This procedure is carried out until the null can no longer be rejected.

In testing the inverse- $U$ relationship hypothesis, we use the following threshold model to conduct the cross-country TR regressions:

$$
C F_{i}=\left\{\begin{array}{ll}
\alpha_{1} \text { OPENF }+\alpha_{2} \text { POLITY }+\alpha_{3} R I R+\beta_{1} G D P P C+\mu_{i}+\varepsilon_{i} \quad G D P P C_{i} \leq \gamma \\
\alpha_{1} \text { OPENF }+\alpha_{2} \text { POLITY }+\alpha_{3} R I R+\beta_{2} G D P P C+\mu_{i}+\varepsilon_{i} \quad G \text { GPPC } i>\gamma
\end{array},\right.
$$

where $C F$ is the average capital flight as a ratio to GDP, OPENF is the gravity-fitted trade openness, POLITY is the political indicator for democracy and autocracy, and RIR is the domestic real interest rate. GDPPC is GDP per capita (PPP), as the threshold variable to be tested. The focus of this estimation is the threshold effect of economic development on capital flight, and the estimation of the exact threshold value. 
Table 5.a

Test results for threshold effects: capital flight.

\begin{tabular}{lll}
\hline Threshold variable & GDPPC & OPENF \\
\hline Test for single threshold & & 6.2803907 \\
Likelihood ratio stat. & 19.890381 & 0.895 \\
Bootstrap $p$-value & $0.001^{* * *}$ & - \\
Threshold estimate & 2974.18 & - \\
95\% confidence int. & {$[1966.33,3195.04]$} & - \\
Test for 2nd threshold & 16.432665 & - \\
Likelihood ratio stat. & $0.003^{* * *}$ & - \\
Bootstrap p-value & 5034.487 & - \\
Threshold estimate & {$[4719.326,14498.57]$} & - \\
$95 \%$ confidence int. & & - \\
Test for 3rd threshold & 7.7335 & - \\
Likelihood ratio stat. & 0.604 & - \\
Bootstrap $p$-value & - & - \\
Threshold estimate & - & \\
$95 \%$ confidence int. & & \\
\hline
\end{tabular}

Notes: This table presents the test results for threshold effects using Hansen (1999) Threshold model. The dependent variable is capital flight. Cross-sectional data are used for 97 countries over 1980-2003. Two variables are tested for the threshold effect: GDP per capita and Trade openness.

${ }^{* * *}$ Significant at $1 \%$.

\subsubsection{Development threshold \& capital flight}

The cross-country data are used for threshold estimations because it allows us to divide country into different stage of development according to their average GDP levels without having to deal with the time effects. In addition, Hansen's threshold regression method is suitable for cross-sectional sample or time series, but not panel data. Owing to data availability, some countries are dropped because of incomplete data in one or more of the explanatory variables. Subject to data availability and outliers, the sample for the threshold estimation covers 97 countries.

Results are shown in Tables 5.a and 5.b. Table 5.a report the likelihood ratio test statistics for the statistical significance of threshold effects as well as their 1000 bootstrap $p$-value. We find that the

Table 5.b

Threshold estimation: dependent = capital flight.

\begin{tabular}{lccc}
\hline Variable/threshold & Stage 1 estimate & Stage 2 estimate & $\begin{array}{c}\text { Stage } 3 \text { estimate } \\
\text { GDPPC }>5034.487\end{array}$ \\
\hline GDPPC & 1.73 & $2974.18<$ GDPPC $\leq 5034.487$ & -0.109 \\
RIR & $(0.58)^{* * *}$ & -0.013 & $(0.054)^{* * *}$ \\
POLITY & -0.17 & $(0.456)$ & -0.004 \\
& $(0.039)^{* * *}$ & 0.010 & $(0.022)$ \\
OPENF & -0.18 & $(0.029)$ & -0.111 \\
& $(0.10)^{*}$ & 0.227 & $(0.074)^{*}$ \\
Constant & -0.03 & $(0.109)^{* * * *}$ & 0.134 \\
& $(0.223)$ & 0.541 & $(0.077)^{* * *}$ \\
Observations & -2.22 & $(0.180)^{* * *}$ & 3.050 \\
$R$-squared & $(1.24)^{*}$ & -2.761 & $(0.760)^{* * *}$ \\
\hline
\end{tabular}

Notes: Values given in parenthesis denotes standard errors. This table reports cross-country regressions using the threshold model, over the period 1980-2003. Dependent variable is the capital flight to GDP ratio. Explanatory variables: GDPPC is the GDP per capita, PPP. OPENF is the gravity model fitted trade openness. POLITY is the political rating of democracy (10) and autocracy $(-10)$. RIR is real interest rate.

* Significant at $10 \%$.

*** Significant at $1 \%$. 
test for a single threshold of GDP per capita is significant with a 1000 bootstrap $p$-value of 0.001 . Furthermore, the test for a second threshold of GDP per capita is also statistically significant with a 1000 bootstrap $p$-value of 0.003 . However, the test for a third threshold level is not significant with a $p$ value greater than 0.60 . These results provide strong evidence that there exist three stages for capital flight in terms of a country's income level. The estimated two threshold levels of income are US\$ 2,974.18 and US\$ 5,034.49 in GDP per capita (PPP): the countries can then be segregated into three development regimes-36 low income economies, 16 middle income counties and 44 high income economies (including the 22 industrial countries). We also test the threshold effect of trade openness on capital flight, using trade openness as the threshold variable. However, the 1000 bootstrap $p$-value for trade openness is 0.895 for single threshold, which is far beyond any acceptable significant level. Therefore, the linear relationship between openness and capital flight cannot be rejected. After finding the estimated values for threshold level of income, it is possible to do the separate OLS regressions by the three different regimes respectively. Table 5.b demonstrates the OLS estimation results for the three groups of countries. We include the economic controls that appear statistically significant in the cross sectional estimation (Table 3). The first column is for countries below the first threshold level and the last column is for countries above the second threshold level. For countries in the first stage (low income countries with GDP per capita less than US\$2,974), the relationship between capital flight and GDP per capita is positive and highly significant; while for countries in the third stage (high income countries with GDP per capita over US\$ 5,034), the relationship is negative and statistically significant. For countries in the second stage, there is no strong and clear relationship between capital flight and the economic development. These estimation results confirm the hypothesis of the nonlinear relationship between capital flight and development threshold, based on the capital income level.

In the threshold regressions, three additional determinants for capital flight are also included, namely openness, polity and real interest rate. According to the coefficients in Table 5.b, real interest rate is negatively correlated with capital flight only for countries in the first stage. In the second and third stages, real interest rate does not influence capital flight. Polity reduces capital flight in the first and third stages but not for countries in the second stage (between approximately US\$3,000 to US\$ 5,000 in GDP per capita), where the effect is the opposite. In terms of trade openness, it is positively correlated with capital fight in the second and third stage of development. Therefore, for countries in different stage of development, the economic fundamental that could encourage or reduce capital flight are not the same.

\subsubsection{Development threshold E net capital outflow}

In order to test if the inverse U-shape is unique for capital flight, we also conduct the threshold regressions on net capital outflow using income and trade openness as the threshold variables. The same cross-sectional data for 97 countries are used for the estimation. Table 6.a presents the estimation results on the threshold effects of GDP per capita and trade openness. The estimation results point two threshold effects of GDP per capita, but not for trade openness, based on the bootstrap $p$-value at the significant level of $10 \%$ level for single threshold and for second threshold. The estimated threshold GDP per capita levels are US\$3,911 and US\$14,427.

Table 6.b presents the OLS regression results of net capital outflows for the three economic development regimes. For countries with GDP per capita below US\$3,911, trade openness is positively associated with net capital outflows, while income, real interest rate and polity are all insignificant. For countries with GDP per capita between US\$3,911 and US\$14,427, none of the variables explains net capital outflows. For countries with GDP per capita over US\$14,427, not only the variables are highly significant, but they also take the expected signs. In all the three stages, net capital outflow is always positively correlated with GDP per capita. This is the opposite of the pattern observed on capital flight, which is negatively associated with the threshold income levels. Except capital flight, the other types of capital flows (i.e. capital inflows, capital outflows, and net flows) are mostly linearly associated with GDP per capita. Hence, the inverse U-shape in the relationship of capital flows and income level is quite unique to capital flight. 
Table 6.a

Test results for threshold effects: net capital outflow.

\begin{tabular}{lll}
\hline Threshold variable & GDPPC & OPENF \\
\hline Test for single threshold & & 7.991 \\
Likelihood ratio stat. & 20.3753 & 0.628 \\
Bootstrap $p$-value & $0.000^{* * *}$ & - \\
Threshold estimate & 3911.44 & - \\
95\% confidence int. & {$[884.626,14427.79]$} & - \\
Test for 2nd threshold & 11.5637 & - \\
Likelihood ratio stat. & $0.066^{*}$ & - \\
Bootstrap $p$-value & 14427.79 & - \\
Threshold estimate & {$[11077.36,15203.92]$} & - \\
$95 \%$ confidence int. & & - \\
Test for 3rd threshold & 9.882 & - \\
Likelihood ratio stat. & 0.127 & - \\
Bootstrap p-value & - & - \\
Threshold estimate & - & - \\
$95 \%$ confidence int. & & \\
\hline
\end{tabular}

Notes: This table presents the test results for threshold effects using Hansen (1999) Threshold model. The dependent variable is net capital outflow. Cross-sectional data are used for 97 countries over 1980-2003. Two variables are tested for the threshold effect: GDP per capita and Trade openness.

* Significant at $10 \%$.

*** Significant at $1 \%$.

\subsection{Robustness checks}

To examine the robustness of our baseline findings (cross section and panel of 5-year averages), we first estimate the panel regressions using annual data. Although there could be considerable noise and measurement error in annual data, particularly for developing countries, it is nevertheless useful to examine the sensitivity of the results to the choice of data frequency. Using the annual data, we re-estimate the panel regressions with time and country effects. Using the sample set of economic controls, Table 7 presents the results, which can be directly compared to the baseline estimation in Tables 3 and 4. Evidently, the results emerging as qualitatively robust are the positive effects of economic growth and financial openness, while the positive effect of GDP per capita on capital flows is significant throughout.

Table 6.b

Threshold estimation: dependent $=$ net capital outflow.

\begin{tabular}{lllc}
\hline Variable/threshold & $\begin{array}{l}\text { Stage } 1 \text { estimate } \\
\text { GDPPC } \leq 3911.44\end{array}$ & Stage 2 estimate & $\begin{array}{c}\text { Stage } 3 \text { estimate } \\
\text { GDPPC }>14427.79\end{array}$ \\
\hline GDPPC & 0.169 & 0.104 & 0.609 \\
RIR & $(0.926)$ & $(0.134)$ & $(0.154)^{* * *}$ \\
POLITY & -0.144 & -0.008 & -0.237 \\
& $(0.091)$ & $(0.025)$ & $(0.090)^{* * *}$ \\
OPENF & -0.130 & -0.062 & -0.823 \\
& $(0.134)$ & $(0.075)$ & $(0.073)^{* * *}$ \\
Constant & 0.837 & 0.052 & 0.154 \\
& $(0.405)^{* * *}$ & $(0.067)$ & $(0.053)^{* * *}$ \\
Observations & -8.338 & -2.612 & -4.930 \\
$R$-squared & $(1.593)^{* * *}$ & $(1.015)^{* * *}$ & $(2.577)^{* * *}$ \\
\hline
\end{tabular}

Notes: Values given in parenthesis denote standard errors. This table reports cross-country regressions using the threshold model. Average data are used for all the variables over the period 1980-2003. Dependent variable is the net capital outflow to GDP ratio. Explanatory variables: GDPPC is the GDP per capita, PPP. OPENF is the gravity model fitted trade openness. POLITY is the political rating of democracy (10) and autocracy $(-10)$. RIR is the annual domestic real interest rate.

Significant at $1 \%$. 
Table 7

Panel regression using annual data.

\begin{tabular}{lllll}
\hline & CFlight/GDP & NetOut/GDP & Inflow/GDP & Outflow/GDP \\
\hline GDPPC & 2.68 & 0.82 & 0.464 & 1.037 \\
GDPPC2 & $(0.513)^{* * *}$ & $(0.293)^{* * *}$ & $(0.096)^{* * *}$ & $(0.091)^{* * *}$ \\
RIR & -0.046 & - & - & - \\
INF & $(0.013)^{* * *}$ & - & - & -0.001 \\
& -0.032 & -0.001 & 0.000 & $(0.00)$ \\
POLITY & $(0.009)^{* * *}$ & $(0.01)$ & $(0.00)$ & 0.000 \\
& 0.003 & 0.000 & 0.000 & 0.000 \\
OPENF & $(0.000)^{* * *}$ & 0.000 & 0.000 & -0.03 \\
& -0.321 & 0.083 & 0.006 & $(0.05)$ \\
GROWTH & $(0.095)^{* * *}$ & $(0.05)$ & $(0.05)$ & -0.664 \\
KAOPEN & -0.56 & -0.469 & -0.574 & $(0.149)^{* * *}$ \\
OVAL & $(0.330)^{*}$ & $(0.188)^{* *}$ & $(0.157)^{* * *}$ & 0.077 \\
& -0.161 & -0.13 & 0.08 & $(0.032)^{* * *}$ \\
Constant & $(0.068)^{* *}$ & $(0.039)^{* * *}$ & $(0.035)^{* *}$ & 0.17 \\
& 0.757 & 0.34 & 0.517 & $(0.18)$ \\
Country dummy & $(0.370)^{* *}$ & $(0.21)$ & $(0.182)^{* * *}$ & 0.001 \\
Year dummy & -0.007 & -0.001 & 0.001 & $(0.00)$ \\
Observations & $(0.003)^{* *}$ & $(0.00)$ & $(0.00)$ & -0.455 \\
$R$-squared & -34.857 & -13.69 & -1.111 & $(3.48)$ \\
\hline
\end{tabular}

Notes: Standard errors in parentheses. This table reports panel estimation results using annual data over the period 1980-2003. Subject to data availability, the panel is not balanced. We include dummy variables for each time period and also for each country to control for time and country specific effects. Dependent variables are the capital flight, net capital outflow, total capital inflow and total capital outflow to GDP ratios. Explanatory variables include: GDPPC is GDP per capita, PPP. GDPPC2 is the square term of GDPPC. OPENF is the gravity model fitted trade openness. POLITY is the political rating of democracy (10) and autocracy ( -10$)$. RIR is the annual domestic real interest rate. INF: Annual domestic inflation rate, consumer prices (annual \%). KAOPEN is the Chinn-Ito measure for capital account openness. OVAL is exchange rate over-valuation. GROWTH is the annual GDP per capita growth rate.

* Significant at $10 \%$.

*** Significant at $5 \%$.

*** Significant at $1 \%$.

Serial correlation may influence the regression on panels. We next include a lagged term of capital flows as an additional explanatory variable; with $C F_{i t-1}$ representing the lagged capital flows:

$$
C F_{i t}=\alpha_{i}+\beta_{1} C F_{i t-1}+\beta_{2} Y_{i t}+\beta_{3} Y_{i t}^{2}+\beta_{4} Z_{i t}^{\prime}+\lambda_{t}+\varepsilon_{i t}
$$

As shown in Table 8, the coefficients of the lagged terms are all significantly positive across capital flow equations, suggesting the important of persistency in capital flow adjustment on the annual basis. Adding these lagged terms does not affect the importance of GDP per capita, economic growth, and financial openness.

\section{Financial turbulence, capital flows, and control measures}

In this section, we offer a case study of two emerging markets. Based on the latest statistics from World Bank, the GDP per capita of Brazil is US\$ 7,990 (in PPP) in 2003 and rises to US\$ 10,055 by the end of 2010. For Korea, its GDP per capita is US\$21,070 in 2003 and increases to US\$27,026 in 2010. Not only these two countries have registered the level of GDP per capita that is above our estimated development threshold level, but they are also among the fast growing emerging economies on average during the past decade. From 2004-07, the average growth of GDP per capita is 3.6 percent for Brazil and 4.4 percent for Korea. In 2008, Brazil's growth is 4.21 percent, drops to -1.52 in 2009 , 
Table 8

Panel regression result using annual data with lagged dependent.

\begin{tabular}{lllll}
\hline & CFlight/GDP & NetOut/GDP & Inflow/GDP & Outflow/GDP \\
\hline GDPPC & 1.633 & -0.081 & 0.482 & 0.807 \\
GDPPC2 & $(0.543)^{* * *}$ & $(0.28)$ & $(0.103)^{* * *}$ & $(0.098)^{* * *}$ \\
RIR & -0.028 & - & - & - \\
INF & $(0.014)^{* *}$ & - & - & -0.001 \\
& -0.027 & -0.008 & 0.000 & $(0.00)$ \\
POLITY & $(0.009)^{* * *}$ & $(0.004)^{*}$ & $(0.00)$ & 0.000 \\
& 0.003 & 0.000 & 0.000 & 0.000 \\
OPENF & $(0.000)^{* * *}$ & 0.000 & 0.000 & -0.013 \\
& -0.261 & 0.047 & 0.015 & $(0.05)$ \\
GROWTH & $(0.101)^{* * *}$ & $(0.05)$ & $(0.05)$ & -0.456 \\
KAOPEN & -0.444 & -0.085 & -0.604 & $(0.152)^{* * *}$ \\
& $(0.35)$ & $(0.18)$ & $(0.170)^{* * *}$ & 0.059 \\
OVAL & -0.149 & -0.121 & 0.079 & $(0.032)^{*}$ \\
& $(0.069)^{* *}$ & $(0.035)^{* * *}$ & $(0.036)^{* *}$ & 0.207 \\
LAG TERM & 0.731 & 0.071 & 0.477 & $(0.18)$ \\
Constant & $(0.371)^{* *}$ & $(0.19)$ & $(0.189)^{* *}$ & 0.000 \\
Country dummy & -0.007 & 0.001 & 0.000 & $(0.00)$ \\
Year dummy & $(0.003)^{* *}$ & $(0.00)$ & $(0.00)$ & 0.631 \\
Observations & 0.254 & 0.451 & 0.213 & $(0.056)^{* * *}$ \\
R-squared & $(0.033)^{* * *}$ & $(0.030)^{* * *}$ & $(0.046)^{* * *}$ & -0.495 \\
\hline
\end{tabular}

Notes: Standard errors in parentheses. This table reports panel estimation results with lagged dependent using annual data over the period 1980-2003. Subject to data availability, the panel is not balanced. We include dummy variables for each time period and also for each country to control for time and country specific effects. Dependent variables are the capital flight, net capital outflow, total capital inflow and total capital outflow to GDP ratios. Explanatory variables include: GDPPC is GDP per capita, PPP. GDPPC2 is the square term of GDPPC. OPENF is the gravity model fitted trade openness. POLITY is the political rating of democracy (10) and autocracy $(-10)$. RIR is the annual domestic real interest rate. INF: Annual domestic inflation rate, consumer prices (annual \%). KAOPEN is the Chinn-Ito measure for capital account openness. OVAL is exchange rate over-valuation. GROWTH is the annual GDP per capita growth rate.

* Significant at $10 \%$.

*** Significant at $5 \%$.

**** Significant at $1 \%$.

and bounces to 6.55 percent in 2010. Korea follows the similar pattern, with the growth rate of 1.98 in 2008, 0.03 in 2009, and 5.88 in 2010.

As a result of the strong growth performance of Brazil and Korea prior to the crisis of 2008, and the subsequent volatile growth rates, the two countries have witnessed some dramatic fluctuations, surges, and stops of capital flows into their economies. From 2004-07, driven by capital inflows, the currencies of Brazil and Korea are markedly appreciating against the US\$; see Figs. 5 and 6. To manage the volatility of capital inflows, Brazil and Korea have introduced a number of control measures. Brazil first announced the introduction of its taxes on investments by foreigners in the local bond market on March 12, 2008. ${ }^{6}$ The tax is a 1.5 percent financial transaction tax, known as the IOF. However, following the collapse of Lehman and the ensuing 2008 global crisis, the tax was subsequent eliminated, together with a 0.38 percent tax on foreign currency loans, on October 23, 2008.

As growth returns in early 2009, foreign capitals are piling into Brazil again and its currency resumes appreciating against the US\$. Brazil introduced a government's 2 per cent tax on foreign portfolio investments aimed at stemming the rapid rise of its exchange rate on October 20, 2009. This inflow

\footnotetext{
${ }^{6}$ The sources of our list of control announcements are extracted from Reuters and Financial Times. See also Magud, Reinhart, and Rogoff (2011) and Qureshi, Ostry, Ghosh, and Chamon (2011).
} 

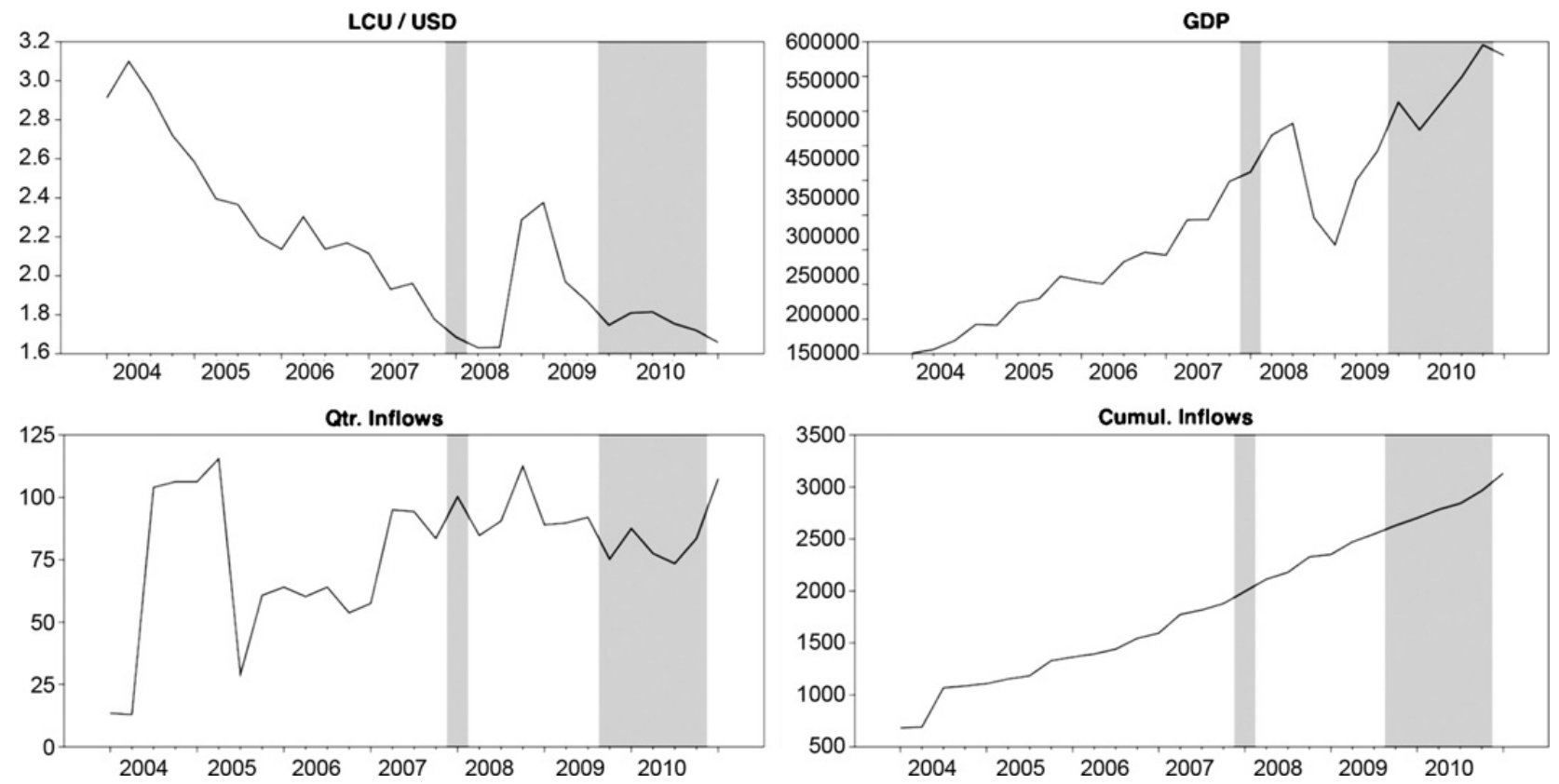

Fig. 5. Brazil, inflows, and capital controls, 2004-11. This figure provides the quarterly plots of exchange per US\$, GDP, and capital inflows. The shaded parts are the periods when major capital control measures are imposed.

tax was followed by a number of measures, including implementing ADR tax of $1.5 \%$ on November 18 , 2009; increasing IOF from 2 to 4 percent on October 4, 2010, and to 6 percent on October 18, 2010. The measures seemingly have their intended effects of stemming the capital inflows and exchange appreciation. Nonetheless, as the Eurozone crisis has intensified in 2010 and the resultant shortage of global liquidity, the IOF has been cut to 2 percent on January 3, 2011. In half a year, Brazil imposes a 1 percent tax on trading in currency derivatives on July 27, 2011. Then on December 1, 2011, Brazil announces that the inflow tax would be reduced.

Towards early 2007, the exchange rate of Korea has been appreciating against the US\$ and the capital inflows surges quarter-on-quarter basis; see Fig. 6. Korea first imposed on April 2007 its restrictions
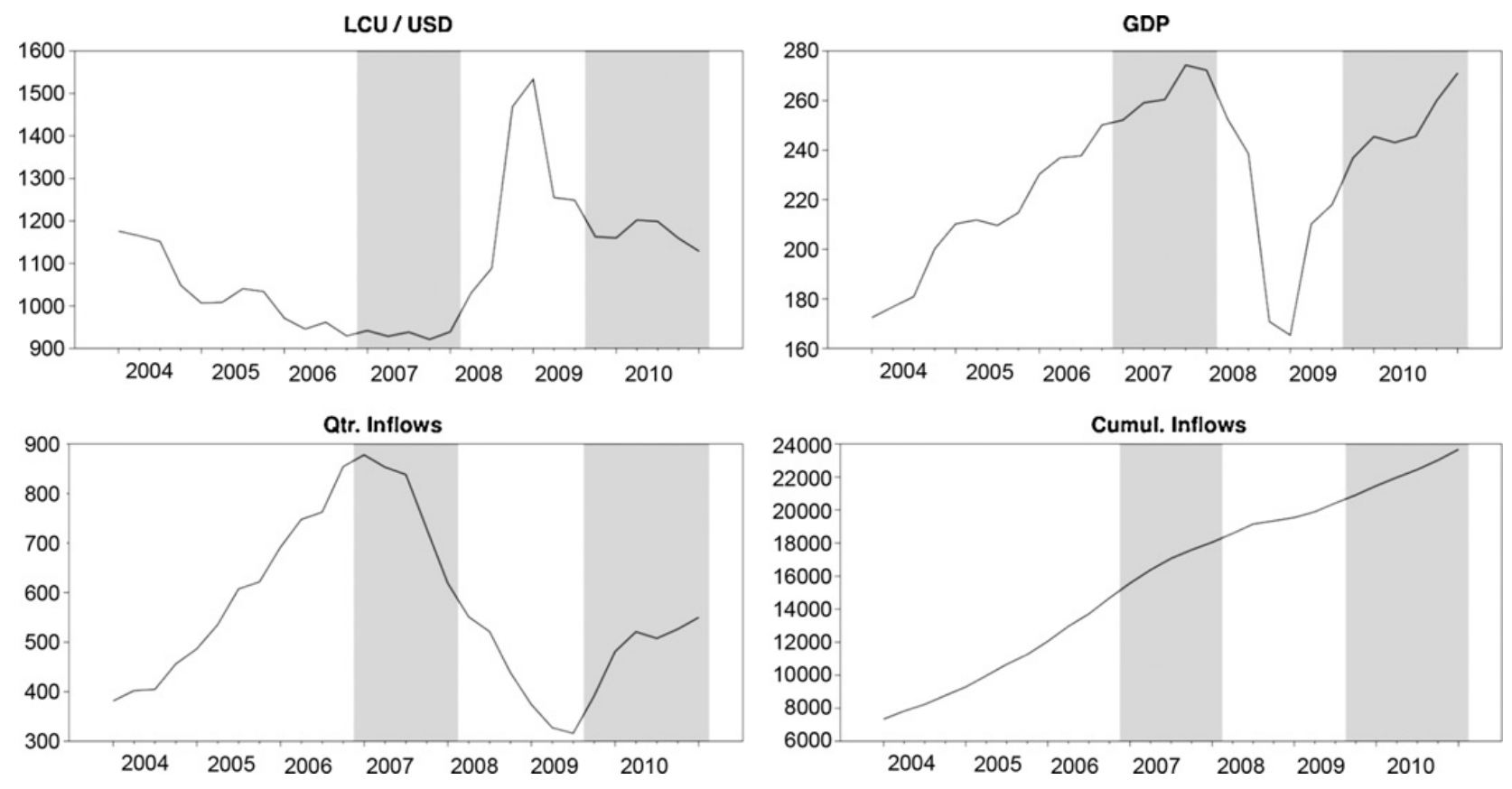

Fig. 6. Korea, inflows, and capital controls, 2004-11. This figure provides the quarterly plots of exchange per US\$, GDP, and capital inflows. The shaded parts are the periods when major capital control measures are imposed. 

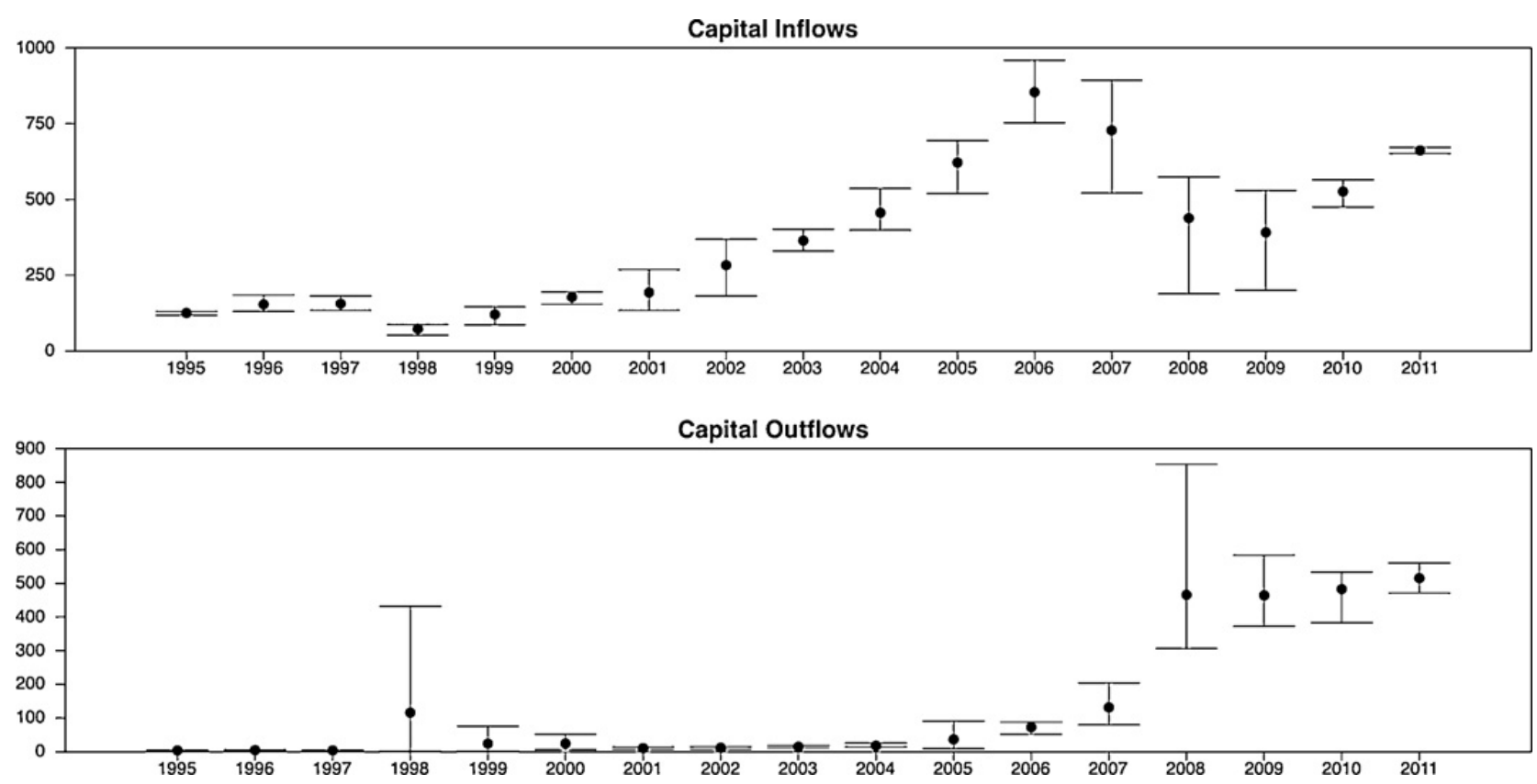

Fig. 7. Korea and volatility of capital flows, 2004-11. This plot shows the volatility of capital inflows and outflows. Based on the quarterly IMF data, each dot denotes the annual average capital flows, while the height of vertical bars provides the maximum and the minimum of quarterly capital flows in each year.

on foreign banks' borrowing dollars from abroad (i.e. to discourage swapping dollars borrowed abroad for Korean won). The measure had a significant effect on foreign banks' cross-border claims on banks in Korea during the second and third quarters of 2007. ${ }^{7}$ While the control seems to have some intended effect, shortly after Korea was hit by sharp capital outflow and currency depreciation due to a mounting concern over its large private external debts, amplified by the onset of 2008 global crisis. These periods are also marked by a huge volatility of capital flows, particularly the outflows, the level not seen since the crisis of 1998, as shown in Fig. 7.

As growth returns in 2009, foreign capitals surge into Korea again. Korea imposed on November 19, 2009 restrictions on banks' foreign exchange transaction to tighten its control over foreign currency liquidity at local banks to make them less vulnerable. The measure is followed by limits on banks' currency forwards trades on June 9, 2010; profit tax on foreigners' investment to curb capital inflows on October 19, 2010; new regulations on equity derivatives trading on January 11, 2011; prohibit financial companies from buying locally issued foreign-currency bonds for domestic use (to temper the resurgent won and reduce short-term foreign debt) on July 19, 2011; plans to impose taxes on the earnings of overseas investors from foreign currency bonds sold in the country in its latest effort to curb rising short-term external debt and counter capital inflows on September 7 , 2011.

The experiences of Brazil and Korea highlight the challenge of managing capital flows in the era of financial globalization. The economies of Brazil and Korea are by now a distance beyond many other emerging markets in terms of their economic development and openness. While the capital flight is no longer the threat to these two countries, the volatility of foreign capitals, both inflows and outflows, still does. The difficulty has to do with the speed that foreign capitals are moving in and out of the country. As the evidence of Brazil and Korea shows, the decisions to implement capital control measures tend to be pushed around by the feedbacks among economic growth, currency appreciation, and the global financial conditions.

7 See Kawai and Lamberte (2010). 


\section{Conclusion}

We report cross-sectional and panel estimation results of capital flow patterns controlling for a number of economic development variables. The variation of capital flows across time and countries is significantly associated with a country's income level as measured by GDP per capita. Capital flight has a unique non-linear relationship with the income level. Using the Hansen threshold estimation method, we identify a three-stage development threshold effect of income level to determine the cutoffs of GDP per capita that affect capital flight across countries. Based on a case study of Brazil and Korea, both of which are beyond the threshold development level, we study their recent management of capital flows and find that a country's decision to implement the control measure may appear fickle and depends on the global market conditions, especially since the crisis of 2008.

\section{Appendix A. Variable List}

Dependent Variables:

Capital Flight: 1980-2003. Volume of annual capital flight in measured in US dollars using the World Bank residue method. The formula for our computation is $C F=\Delta D e b t+F I-C A D-\triangle F R$, where all items are annual data measured in US dollars for current year price index. Data on foreign investment, current account deficit and change in foreign reserve are from the World Development Indicators (WDI) 2005. Data on change in external debt for most of the developing countries are from WDI, with some supplemental data from Source OECD. Data on external debt for industrial countries are from the National Accounts of Source OECD, under the term of Net lending (borrowing).

CFlight/GDP: 1980-2003. Capital flight as a ratio of GDP. Data on GDP for all countries are from WDI, in current year US dollars.

Net Capital Outflow: 1980-2003. Data on net capital outflow, which is represented by a current account surplus, are the sum of net exports of goods, services, net income, and net current transfers. Data are obtained from the WDI in current U.S. dollars. A positive figure, or a surplus, implies net capital outflow from and country, and a negative figure implies net capital inflow.

NetOut/GDP: 1980-2003. Net capital outflow as a ratio to GDP. Data on GDP for all countries are from WDI, in current year US dollars.

Total Capital Inflow: 1980-2003. It is the sum of short- and long-term capital inflows as reported under FDI inflow and portfolio inflow in the balance of payment. Data on FDI and portfolio investment flows are obtained from the International Financial Statistics (Lines 78bed and 78bgd). The dataset covers 119 countries over the period of 1980-2004.

Inflow/GDP: 1980-2003. Total capital inflow as a ratio to GDP. Data on GDP for all countries are from WDI, in current year US dollars.

Total Capital Outflow: 1980-2003. Volume of annul normal capital outflow measured in current US dollars. Normal capital outflow is computed by the sum of Foreign Direct Investment outflow and portfolio outflow. Data on FDI and portfolio outflow are from the International Financial Statistics (lines 78bdd and 78bfd respectively).

Outflow/GDP: 1980-2003. Total capital outflow as a ratio to GDP. Data on GDP for all countries are from WDI, in current year US dollars.

Explanatory Variables:

GDPPC: 1980-2003. GDP per capita based on purchasing power parity (PPP, constant 2000 international \$). GDP PPP is gross domestic product converted to international dollars using purchasing power parity rates. An international dollar has the same purchasing power over GDP as the U.S. dollar has in the United States. Data are obtained from WDI in constant 2000 international dollars.

POLITY: $1980-2003$. It is the POLITY2 index from the Polity IV dataset, with a range from -10 to 10 ( $-10=$ high autocracy; $10=$ high democracy). It is a combined polity score computed by subtracting AUTOC from DEMOC. DEMOC-Democracy Score (numeric) Range $=0-10(0=$ low; $10=$ high): general openness of political institutions. The 11 -point Democracy scale is constructed additively. AUTOC-Autocracy Score (numeric) Range $=0-10(0=$ low; $10=$ high): general closedness of political institutions. The 11-point Autocracy scale is constructed additively.

INST (Institutions): 1984-2000. Follow Alfaro 2008, we construct a yearly composite index using International Country Risk Guide's (ICRG) variables from the PRS Group. The composite index is the sum of the 11 indices: investment profile, government stability, internal conflict, external conflict, no-corruption, non-militarized politics, protection from religious tensions, law and order, protection from ethnic tensions, democratic accountability, and bureaucratic quality. This index takes values from 0 to 10 for each country, where a higher score means lower risk.

SCHOOL: Years of Schooling: 1970, 1975, 1980, 1985, 1990, 1995, 1999. Average years of secondary, higher and total schooling in the total population. Data are from Barro, Robert J. and Jong-Wha Lee (2000), International Data on Educational Attainment: Updates and Implications, Center for International Development at Harvard University (CID).

CAP INX: 1980-2000. Restrictions to Capital Mobility constructed by Edwards (2005). It is a new index on capital mobility that combines information from Quinn (2003) and Mody and Murshid (2002). The new index has a scale from 0 to 100, where higher numbers denote a higher degree of capital mobility; a score of 100 denotes absolutely free capital mobility. 
KAOPEN: 1980-2003. Kaopen is an index to measure a country's degree of capital account openness constructed by Chinn and Ito (2006). It is based on the binary dummy variables that codify the tabulation of restrictions on cross-border financial transactions reported in the IMF's Annual Report on Exchange Arrangements and Exchange Restrictions. Source: Chinn-Ito (2006) Financial Openness measure.

INF: 1980-2003. Annual domestic inflation rate, consumer prices (annual \%) Inflation as measured by the consumer price index reflects the annual percentage change in the cost to the average consumer of acquiring a fixed basket of goods and services that may be fixed or changed at specified intervals, such as yearly. The Laspeyres formula is generally used.

GROWTH: 1980-2003. GDP per capita growth (annual \%) from the WDI. It is the annual percentage growth rate of GDP per capita based on constant local currency. GDP per capita is gross domestic product divided by midyear population.

RIR: 1980-2003. Real interest rate (\%) from the WDI. It is the lending interest rate adjusted for inflation as measured by the GDP deflator.

OPENF: 1980-200. Trade openness by gravity model fitted value constructed by Andrew K. Rose 2002.

OVAL: 1980-1998. Over or under-valuation of the exchange rate, calculated by dividing the black-market exchange rate by the official exchange rate $\left(S^{*} / S-1\right)$. A positive figure indicates over-valuation and a negative figure indicates undervaluation. Source: IFS and World Currency Year Book.

\section{Appendix B. Country list (by thresholds in Table 6.b)}

Countries in Stage 1, GDPPC $\leq$ US\$3911.44 (54 Countries):

$\begin{array}{ll}\text { Albania, } & \text { Guatemala, } \\ \text { Angola, } & \text { Haiti, } \\ \text { Bangladesh, } & \text { Honduras, } \\ \text { Benin, } & \text { India, } \\ \text { Bolivia, } & \text { Indonesia, } \\ \text { Burkina Faso, } & \text { Jamaica, } \\ \text { Burundi, } & \text { Kenya, } \\ \text { Cameroon, } & \text { Lao PDR, } \\ \text { Cape Verde } & \text { Lesotho } \\ \text { Central African Republic, } & \text { Madagascar, } \\ \text { Chad, } & \text { Mali, } \\ \text { China, } & \text { Mauritania, } \\ \text { Comoros } & \text { Morocco, } \\ \text { Congo, Rep., } & \text { Mozambique, } \\ \text { Cote d'Ivoire } & \text { Nepal, } \\ \text { Ecuador, } & \text { Nicaragua, } \\ \text { Egypt, Arab Rep., } & \text { Niger, } \\ \text { Ghana, } & \text { Nigeria, }\end{array}$

Countries in Stage 2, US\$3911.44< GDPPC $\leq$ US $\$ 14427.29$ (44 Countries):
Antigua and Barbuda

Argentina

Bahrain

Belize

Botswana

Brazil

Bulgaria

Chile

Colombia

Costa Rica

Dominica

Dominican Republic

El Salvador

Fiji

Gabon

Grenada
Hungary
Iran, Islamic Rep.
Jordan
Korea, Rep.
Lebanon
Malaysia
Malta
Mauritius
Mexico
Namibia
Oman
Panama
Paraguay
Peru

Countries in Stage 3, GDPPC > US\$14427.29 (32 Countries):

Australia

Austria

Bahamas, The

Barbados

Belgium

Bhutan

Canada
Pakistan

Papua New Guinea

Philippines,

Rwanda,

Samoa

Senegal,

Sierra Leone,

Solomon Islands

Sri Lanka,

Sudan

Swaziland

Syrian Arab Republic,

Tanzania,

Togo,

Uganda,

Vanuatu

Zambia,

Zimbabwe

Poland,

Portugal,

Romania

Saudi Arabia

Seychelles

South Africa,

St. Kitts and Nevis

St. Lucia

Thailand,

Trinidad and Tobago,

Tunisia,

Turkey

Uruguay,

Venezuela, RB

New Zealand

Norway

Sao Tome and Principe

Singapore

Spain

Suriname

Sweden 


$\begin{array}{lll}\text { Cyprus } & \text { Kuwait } & \text { Switzerland } \\ \text { Denmark } & \text { Libya } & \text { United Kingdom } \\ \text { Finland } & \text { Maldives } & \text { United States } \\ \text { France } & \text { Netherlands } & \end{array}$

\section{References}

Alfaro, L., \& Hammel, E. (2007). Capital flows and capital goods. Journal of International Economics, 72(1), 128-150.

Alfaro, L., Kalemli-Ozcan, S., \& Volosovych, V. (2008). Why doesn't capital flow from rich to poor countries? An empirical investigation. The Review of Economics and Statistics, 90(2), 347-368.

Chinn, M. D., \& Ito, H. (2006). What matters for financial development? Capital controls, institutions, and interactions. Journal of Development Economics, 61(1), 163-192.

Chinn, M. D., \& Ito, H. (2008). A new measure of financial openness. Journal of Comparative Policy Analysis, 10(3), $307-320$.

Collier, P., Hoeffler, A., \& Pattillo, C. (1999). Flight capital as a portfolio choice. Policy research working paper series 2066. The World Bank.

Cuddington, J. T. (1986, March). Capital flight: Estimates, issues, and explanations. In Princeton studies in international finance (Vol. 58, pp. 1-44). Princeton: Princeton University.

Cumby, R. E., \& Levich, R. M. (1987). On the definition and magnitude of recent capital flight (pp. 27-67). Capital flight and third world debt. Washington DC: Institute for International Economics.

Devereux, M. B., \& Sutherland, A. (2009). A portfolio model of capital flows to emerging markets. Journal of Development Economics, (89), 181-193.

Dooley, M. (1986). Country-specific risk premiums, capital flight, and net investment income payments in selected developing countries. Mimeo, International Monetary Fund, Washington, D.C.

Edwards, S. (2005, March). Capital controls, sudden stops, and current account reversals. NBER working paper 11170. Cambridge, Mass.: National Bureau of Economic Research.

Edwards, S. (2007). Capital controls, capital flow contractions, and macroeconomic vulnerability. Journal of International Money and Finance, 26(5), 814-840.

Edwards, S., \& Rigobon, R. (2009). Capital controls on inflows, exchange rate volatility and external vulnerability. Journal of International Economics, 78(2), 256-267.

Evans, M. D. D., \& Hnatkovska, V. (2005). International capital flows, returns and world financial integration. NBER working paper 11701.

Gourinchas, P.-O., \& Jeanne, O. (2007). Capital flows to developing countries: The allocation puzzle. NBER working paper no. 13602.

Hansen, B. E. (1999). Threshold effects in non-dynamic panels: Estimation, testing, and inference. Journal of Econometrics, 93(2), 345-368.

Hansen, B. E. (2000). Sample splitting and threshold estimation. Econometrica, 68(3), 575-603.

Honig, A. (2008). Addressing causality in the effect of capital account liberalization on growth. Journal of Macroeconomics, 30(4), 1602-1616.

Jones, R. W., Coelho, I., \& Easton, S. T. (1986). The theory of international factor flows: The basic model. Journal of International Economics, 20(3-4), 313-327.

Ju, J., \& Wei, S.-J. (2006). A solution to two paradoxes of international capital flows. NBER working paper 12668.

Kawai, M., \& Lamberte, M. B. (2010). Managing capital flows: The search for a framework. Glos, UK: ADB Institute, Edward Elgar Publishing Limited.

Kindleberger, C. P. (1938). International short-term capital movements. Journal of the American Statistical Association, 33(201), 296-298.

Lane, P. R., \& Milesi-Ferretti, G. M. (2002). External wealth, the trade balance, and the real exchange rate. IMF working papers 02/51, International Monetary Fund.

Lane, P. R., \& Milesi-Ferretti, G. M.(2002). Long-term capital movements, NBER chapters (Vol. 16, pp. 73-136). NBER macroeconomics annual 2001 National Bureau of Economic Research, Inc.

Lessard, D. R., \& Williamson, J. (1987). Recapitalizing the third world: Toward a new vision of commercial financing for less developed countries. Working papers 1946-87. Massachusetts Institute of Technology (MIT), Sloan School of Management.

Lucas, R. E., Jr. (1990). Why doesn't capital flow from rich to poor countries? The American Economic Review, 80(2), 92-96.

Mody, A., \& Murshid, A. P. (2002). Growing up with capital flows. Journal of International Economics, 65(1), 249-266.

Magud, N.E., Reinhart, C.M., \& Rogoff, K.S. (2011). Capital controls:myth and reality-a portfolio balance approach. NBER Working Paper 16805. National Bureau of Economic Research, Inc.

Ndikumana, L., \& Boyce, J. K. (2001). Is Africa a net creditor? New estimates of capital flight from severely indebted sub-Saharan African countries, 1970-98. Journal of Development Studies, 38(2), 27-56.

Ndikumana, L., \& Boyce, J. K. (2003). Public debts and private assets: Explaining capital flight from sub-Saharan African countries. World Development, 31(1), 107-130.

Neumann, R. M., Penl, R., \& Tanku, A. (2009). Volatility of capital flows and financial liberalization: Do specific flows respond differently? International Review of Economics and Finance, 18(3), 488-501.

Prasad, E.S., Rajan, R.G. \& Subramanian, A. (2007). Foreign capital and economic growth (Vol. 38 (2007-1), pp. 153-230). Brooking papers on economic activity, Economic studies program. The Brookings Institution.

Quinn, D. P. (2003). Capital account liberalization and financial globalization, 1890-1999: a synoptic view. International Journal of Finance and Economics, 8(3), 189-204.

Qureshi, M.S. \& Ostry, J.D. \& Ghosh, A.R. \& Chamon, M. (2011). "Managing capital inflows: the role of capital controls and prudential policies," NBER Working Papers 17363, National Bureau of Economic Research, Inc. 
Reinhart, C. M., \& Rogoff, K. S. (2004). Serial default and the 'Paradox' of rich-to-poor capital flows. American Economic Review, 94(2), 53-58.

Verdier, G. (2008). What drives long-term capital flows? A theoretical and empirical investigation. Journal of International Economics, 74(1), 120-142.

Wincoop, E., \& Tille, C. (2010). International capital flows. Journal of International Economics, 80(2), 157-175. 